\title{
Exploring the Relationship Between Educational Credentials and the Earnings of Immigrants
}

\author{
Maria Adamuti-Trache \\ The University of British Columbia \\ Vancouver, British Columbia, Canada
}

\section{Robert Sweet}

Lakehead University

Thunder Bay, Ontario, Canada

\begin{abstract}
The study uses the 2002 Ethnic Diversity Survey (EDS) to examine the relationship between immigrants' educational credentials and earnings. Three aspects of an individual's credentials are considered: country of origin, level of education, and field of study. In addition, we examine the constraining effects of gender and visible minority status on the ability of immigrants to negotiate the value of their educational credentials in the Canadian labour market.
\end{abstract}

Key Words: Immigrants, visible minority status, gender, Canadian labour market 
Maria Adamuti-Trache and Robert Sweet

\section{Résumé}

Cette étude s'appuie sur les données de l'Enquête sur la diversité ethnique (EDE) pour examiner la relation entre les niveaux d'accréditation académique des immigrants et leurs salaires. Trois aspects de l'accréditation sont considérés : le pays d'origine, le niveau d'éducation et le champ d'étude. De plus, nous examinons aussi l'effet contraignant les statuts de sexe et de minorité visible peuvent causer sur la capacité des immigrants à négocier la valeur de leurs accréditations sur le marché du travail canadien.

Mots clés : Les immigrants, le statut de minorité visible, les sexes, le marché du travail canadien.

\section{Introduction}

Immigration has become an important source of highly skilled labour for the knowledge-based sectors of Canada's economy. Immigration policy since the 1990s has emphasized newcomers' education that contributes up to $25 \%$ of the point-based selection scale in choosing among candidates. This resulted in a significantly higher level of educational attainment among recent immigrants as compared to those from previous immigration waves. "In 2001, 46\% of immigrants aged 25 to 54 who arrived from 1996 to 2000 held at least a bachelor's degree, compared with only $23 \%$ of the same age group who arrived from 1986 to 1990" (Statistics Canada, 2003a, p. 86).

A selective immigration system, then, responds to Canada's need for highly skilled workers educated to the post-secondary level. However, from a policy perspective, it not only is necessary to find and attract well-educated immigrants, it also is necessary to integrate them quickly and efficiently into the workforce in order that their skills may be effectively utilized in advancing the goals of the economy and society. The task of integration has proven more difficult than many expected. For instance, in 2001, the employment rate of 25to 54-year-olds was only $69 \%$ among recent university-educated immigrants (i.e., those who immigrated from 1996 to 2000) as compared to $90 \%$ for nativeborn (Statistics Canada, 2003a). 
Recent immigrants with university degrees earned about $31 \%$ less than their Canadian-born counterparts, whether or not they worked in highly or lower skilled jobs. For instance, in management, "men aged 25 to 54 who immigrated during the 1990s, and held a university degree, earned between 50 and 60 cents for every dollar earned by their Canadian born counterparts" (Statistics Canada, 2003b, p. 13). Employment discrepancies and earning gaps experienced by immigrants who arrived in the latest decade are maintained over longer periods of time as compared to previous waves of immigration. Whether or not this is related to changing demands of the Canadian labour market or to increased competition with an increasingly well-educated Canadian-born population is subject to debate. The assessment of the Conference Board of Canada concludes that "Immigrants have lower incomes due to transition difficulties; insufficient working knowledge of English and French; inadequate recognition of their educational credentials; and, possibly, discrimination" (2004, p.15).

On the other hand, Reitz (2000), Picot (2004) and others have pointed to the increasing levels of post-secondary participation among the native-born as a source of credential competition in the labour market. This more competitive environment then affects immigrants' ability to negotiate the worth of their credentials when seeking employment and to gain recognition of their skills once employed. Labour market opportunities for immigrants are, however, constrained by other factors. These include not only individual differences such as language competence and relevant work experience but also social structural biases. For example, the Canadian labour market remains highly gendered a well as ethnically and racially biased. As Li (2001) observes, individual differences and social structures often combine to limit the utility of immigrants' educational credentials. The existing research on the labour market experiences of immigrants typically examines the relationship between earnings and educational level - measured as years of schooling, or college diploma versus university degree. Among university graduates, however, the labour market value of their credentials can be evaluated along at least three dimensions: level, country of origin, and field of study (Anisef, Sweet \& Frempong, 2002). How these dimensions relate to earnings and are differentially affected by individual differences and the social organization of the labour market are issues that need further examination.

The purpose of this study is to provide a more detailed assessment of the relationship between immigrant post-secondary credentials and labour market outcomes. The study employs data obtained from the 2002 Ethnic Diversity Survey (EDS) which sampled some 43,000 individuals who had responded to the long form of the 2001 Census to extend and elaborate previous research that examined the relationship between the credentials and earnings of university graduates. At the same time, important individual differences and social 
Maria Adamuti-Trache and Robert Sweet

structural variations in the labour market can be considered in qualifying this relationship. The analysis is guided by the following questions:

- How do the social structures of gender and visible minority status and individual differences in language competence and work experience qualify the relationship between educational (university) credentials and the earnings of immigrants and nonimmigrants?

- Are there differences by gender and visible minority status in immigrants' earnings based on their educational credentials, controlling for individual differences?

\section{Background}

Previous research directed toward understanding the earnings gap between immigrants and native-born Canadians, has adopted different theoretical stances. Broadly, these comprise human capital theory, social structural theory, and social capital theory.

Human capital theory assumes that investment in education is rewarded by increased earnings and improved working conditions. The demands for a highly-educated workforce have raised the education premium, and university education receives particular recognition in the labour market (Lavoie and Roy, 1998; Baldwin and Beakstead, 2003). Between 1991 and 2000, university graduates registered a 3-6\% lower unemployment rate and up to $50 \%$ higher average earnings as compared to all educational levels groups (Statistics Canada, 2003c, 2003d). And, in general, higher levels of education are associated with enhanced earnings (Finnie, 2001; Allen, Harris and Butlin, 2003; Heisz, 2003; Morissette, Ostrowsky and Picot, 2004). Human capital theory represents a useful framework within which to examine the effects of educational credentials, work experience, and language skills on labour market success. It is, however, unable to provide a comprehensive account of earnings inequalities in general and immigrant and native-born earnings differentials in particular (Li, 2003). Other social and structural characteristics of the labour market impinge on the relationship between educational credentials and earnings (Beach \& Worswick, 1993; Kunz, Milan \& Schetagne, 2000). 


\section{Social Structures}

Hiebert (1997), for example, argues that labour markets are never neutral and the value of an individual's credential is distorted by gender, social class, race, and nativity. While social structures constrain and limit the value of immigrant educational credentials there remains some scope for individual agency in the process of negotiating the worth of one's educational credentials. Social context in this instance involves dimensions of identity, attachment and trust among immigrant groups and between immigrants and members of the host society (Kunz, 2003). Anisef, Sweet \& Frempong (2002) note the possession of cultural capital is equally important. This includes familiarity with local labour market conditions and the understanding of social codes and modes of interacting in achieving job search and career advancement goals. This study is built on a human capital argument and explores the role of social structures in the negotiation of credentials in the labour market.

Research that documents the experiences of immigrants in the Canadian labour market emphasizes the continuing decline in earnings of high skilled immigrants through that decade and how the earnings gap reflects the complex intersection of social structural features (Boyd, 1992; Davies \& Guppy, 1998). Immigrants enter a labour market that is already gendered and systemically biased (racist). Access to and success in well-remunerated occupations is overtly or covertly controlled by social structural features (Finnie, 2001; Anisef, Sweet \& Frempong, 2002). Jobs that are worth more in the current labour market are more likely to be open to privileged social groups. For instance, in knowledge-based occupations for which the rate of growth doubled between 1971 and 1996 and wages were more competitive (e.g., professional, management and technical groups), women's participation shows a growth factor of only 1.3 as compared to 2.3 for their male counterparts (Beakstead \& Vinodrai, 2003).

It is frequently argued that immigrants' earnings in the Canadian labour market are lower than native-born Canadians because of the lower market value attached to their educational qualifications, and not necessarily due to a lack of mechanisms for the formal recognition of credentials. Li (2001) explores the market worth of foreign credentials and whether immigrants with Canadian degrees have earning parity with Canadian-born degree holders. He uses 1996 Census data and compares groups differentiated by gender, visible minority status, and nativity/age at immigration. His study suggests that gender, race, immigrant status, and type of credentials create multiple sources of inequality. These combine to marginalize some groups more than others. For example, immigrant women of visible minority origin are particularly disadvantaged. 
Maria Adamuti-Trache and Robert Sweet

While such social structures obviously constrain immigrant integration, employers nevertheless do take into account the human capital and personal characteristics of their current and potential employees. Work experience gained in the Canadian labour market and official language proficiency (English or French) are individual factors that make credentials more attractive. However, on average, immigrant graduates are less well remunerated than native-born graduates who possess equivalent educational qualifications and are unlikely to have their earnings converge with the income levels of native-born Canadians (Frenette and Morissette, 2003; Picot and Hou, 2003). Attempts to explain these disparities have met with limited success for reasons associated with the specification of the credentials themselves and an inability to identify the salient social structural factors and individual differences that qualify this relationship.

\section{Individual Differences}

\section{Language Competence}

Immigration policies throughout the 1990's assigned up to $24 \%$ of the pointbased selection scale to language proficiency, which is perhaps essential giving the changing characteristics of recent immigrants who are less likely of being English-speaking groups. As Picot (2004) points out, the shift in source origins and home language may have contributed to the increasing earnings gap between immigrants and the native-born Canadians. Even if language barriers are essential to social and economic integration, there is no clear evidence of their relationship to education, although (English or French) language skills are more likely found among those with higher levels of education. Competence in one of Canada's official languages as well as one (or more) other languages confers all the benefits of bilingualism. Where English or French is the language of the workplace, lack skill in either of these languages is a distinct handicap.

\section{Work Experience}

The immigration policy of 1990 assigned up to $21 \%$ of the point-based selection scale to at least 4 years of work experience in sectors recognized by the National Occupational Classification (NOC). Aydemir and Skuterud (2004) used the microdata files of the Canadian Censuses between 1981 and 2001 to look at earnings for immigrants and Canadian-born males, 18 to 54 year old, and employed on a full-year, full-time basis. Years of labour market experience were considered together with years of schooling, cohort period, years since immigration. About one-third of the overall deterioration in the entry earnings of immigrants was explained by the absence or lack of relevance of foreign 
labour market experience. This is more pronounced for immigrants from nontraditional source countries. Reitz (2001) shows that immigrants receive lower earnings premiums for work experience as compared to Canadian born, due largely to pay inequality within occupations (i.e., difficulties ascending the earnings ladder of particular firms) rather than non-recognition of qualification entering high-skilled occupation.

\section{Educational Credentials}

Reitz (2005) recently reviewed policy issues related to credential recognition and skills under-utilization by immigrants and concluded that despite rising educational credentials among recent immigrants and high levels of fluency in one official language, immigrants' employment and earnings continue to decline. Reitz argued that problems in the education-work relationship are caused not by the inadequate skill levels of immigrants, but rather by the way they are recognized and utilized in Canadian workplaces. Earnings trends differ by occupation and are associated with different human resource practices. Immigrants are, for example, more successful in professions where more rigorous credential-assessment practices have been implemented. Reitz nevertheless suggests that the skill-assessment process is constrained by institutional procedures that are too complex and overlapping. The author recommends institutional change to reduce and rationalize the myriad of employers, licensing bodies, unions, post-secondary institutions, and credential evaluation providers involved in the skills assessment process.

While institutional changes in the recognition and utilization of immigrants' knowledge and skills are needed, their implementation requires a better understanding of the nature of post-secondary credentials and their functioning in the Canadian labour market. To adequately discuss the education-work relationship, it is necessary to define education credentials (as assessed by employers) beyond merely the counting of 'years of schooling' (Ferrer and Riddell, 2004). In the case of post-secondary graduates, at least three dimensions are relevant: origin, or the country in which the degree was obtained; educational level, typically involving a distinction between college and university credential or, among university graduates, a distinction between baccalaureate and graduate degrees; and field of study, contrasting liberal arts and vocational or professional fields. Few studies have considered all three dimensions of immigrants' credentials in predicting earnings (Anisef, Sweet \& Frempong, 2003; Sweetman \& McBride, 2004). 
Maria Adamuti-Trache and Robert Sweet

\section{Origin of Education}

The country in which the degree was obtained has an impact on how quickly and effectively immigrants integrate in the labour market. Thompson (2000) advances the hypothesis that if immigrants cannot find employment appropriate to their education, skills and experience this can be explained either by a lower level or quality of their education or by the partial compensation that employers give to their credentials. Although there was a substantial increase of the number of highly educated immigrants between 1990 and 1999 (45\% as compared to $20 \%$ ), there also was a change in the composition of immigrants by country of origin. Increasingly, immigrants came from developing nations with post-secondary systems that often possessed fewer resources. In any case, Canadian employers were reluctant to recognize their credentials. The region where one's education was obtained matters: preferential employment is given to credentials obtained in Canada, Northern Europe and the United States.

\section{Educational level}

As indicated, most studies differentiate levels of education by years of schooling (Ferrer and Riddell, 2004). Sweetman and McBride (2004) predicted earnings by level of education as well as other features of post-secondary credentials possessed by college and university graduates. Three educational levels (college or trades certificate, Bachelor's or Master's degree) were considered in their analysis and showed clear differences in earnings. In this study the relationship between immigrants' earnings and their level of education paralleled that found in previous comparisons of earnings of college and university graduates conducted with non-immigrant groups (Allen, 1998).

\section{Field of study (FOS)}

Few studies of credentials have considered field of study (FOS) although this gives an indication of the type of skill possessed by immigrants and their occupational preferences (Boothby, 2000; Finnie, 2001; Anisef, Sweet \& Frempong, 2003). It also allows one to understand which skills are easily transferable to the Canadian labour market; or which type of knowledge is relevant to the new Canadian knowledge economy. In Sweetman \& McBride's (2004) study, for instance, the distribution by field of study shows that female and also male Canadian-born groups are very likely to have a teaching degree while immigrants are much more likely to be in engineering and applied sciences, or in math, physical sciences and medicine: "In general, female immigrants are more likely to enter 'traditionally male', and higher paying, 
disciplines that are science or math related than are Canadian-born females" (p. 48). Their findings show that FOS explained $14 \%$ of the variance in earnings between Canadian-born and immigrant groups. These results are similar to those of Anisef, Frempong and Sweet (2002) who used earlier 1996 Census data.

\section{Method}

\section{Objectives}

The purpose of this study is to provide a more accurate assessment of the relationship between immigrant post-secondary credentials and earnings controlling for the social structures of gender and visible minority status and individual differences in language competence and work experience. Respondents who possess a university degree (obtained in Canada or elsewhere) comprise the research sample. Fields of study are classified in liberal arts and applied following Lin, Sweet and Anisef's (2003) scheme. We begin the analysis by constructing separate profiles of respondents who possess university degrees. These profiles are based on gender, visible minority and immigrant vs. non-immigrant variables -- the individual differences of primary interest in the study. This leads to 8 main groups for which other background, educational and employment information will be displayed. We next model the (log) earnings of immigrants and native-born using OLS regression, to assess the relative importance of structural, individual and educational factors in determining earnings for those respondents who earned income in 2001 through employment. Finally, we examine differences in immigrants' earnings in relation to their credential origin, level, and field of study.

\section{Data}

The data employed in the study were drawn from the 2002 Ethnic Diversity Survey (EDS) conducted by Statistics Canada in 2001. The EDS contains data from the 2001 Census that add information on respondents' education and employment in 2000 . The specific Census data used in this paper refer to postsecondary programs. This allows the identification of respondents' minor and major fields of study according to Statistics Canada classification. Based on the minor fields of study, we aggregate academic programs of university degree holders into two categories: liberal arts and applied fields. ${ }^{1}$ 
Maria Adamuti-Trache and Robert Sweet

\section{Sample}

The working sample was defined based on the following criteria:

- respondents who were Canadian born or landed immigrant

- respondents who possess a university degree (based on EDS survey).

- respondents who clearly declared their major field of study (Census survey).

- respondents between 25-64 years of age (i.e., expected to be active in the labour market)

- respondents who declared employment as their main source of income and reported earnings.

This selection ensures that the analysis focuses on those who tested the value of their credentials in the labour market. Rescaled weights are computed from the cross-sectional survey weights to correctly estimate proportions in the population. The research sample for the analysis consisted of 5320 cases. Basic demographic characteristics of the research sample are as follows:

- The proportion of women in the research sample is $48 \%$.

- It contains $28 \%$ immigrants, as compared to $21 \%$ in the EDS sample. This difference is mainly due to the larger proportion of university graduates within immigrant group.

- Average age is 41 years.

- Nineteen per cent of respondents declared they belonged to a visible minority group, as compared to $12 \%$ only in the whole EDS sample.

\section{Variables}

The variables selected to build profiles and examine the basis for earnings differences are immigrant status, visible minority status, and gender. The individual difference components of the profiles comprise an index of Canadian work experience and an index of workplace language disadvantage.

Age and age of arrival are typically employed as proxies for immigrants' Canadian work experience. Because our sample was restricted to university graduates and an age range of 25-60 years, we constructed a measure of Canadian work experience that employed neither of these variables directly but rather incorporated both in an index of relevant Canadian work experience. Specifically, we defined Canadian work experience as current age less 25 regardless of immigrant status, which is in agreement with other research that uses age as a proxy for work experience of university graduates. However, for 
immigrants older than 25, Canadian work experience is defined as the difference between their age and age at arrival. For this group, a positive association between age and work experience is not to be expected as older immigrants who have arrived relatively recently are likely to encounter considerable difficulty in securing well-paid jobs (Anisef, Sweet \& Frempong, 2003). A squared term for work experience was used in modeling earnings (Reitz, 2001).

We also constructed a 'language disadvantage scale' that indicates whether the language at work (English or French) is different from the language spoken in the home. We assume this index describes the required degree of adjustment an individual must make to the communicative demands and, more broadly, the social conditions of the workplace. Immigrants whose home language is neither English nor French find this adjustment more difficult than those who are fluent in the language of the workplace. Complete workplace and home-language consistency is indicated by a ratio of 0 ; at the other extreme, a lack of proficiency in the language of workplace is indicated by 1 .

The different dimensions of educational credentials are indicated by origin of education - we specifically distinguish between education obtained in Canada, United States or Great Britain, Europe and Other countries. Level of education distinguishes the undergraduate from graduate degree, and field of study is categorized as either liberal arts or applied studies.

\section{Findings}

We first compared the Canadian-born and immigrant groups, followed by an analysis within the immigrant groups differentiated by gender and visible minority status. Results are presented according to Statistics Canada data requirements. ${ }^{2}$

\section{Profiles of Respondents}

In Table 1 we present descriptive statistics of individual difference variables across groups defined by immigrant status, visible minority status, and gender. The average age of the research sample is 41 , while that of Canadian-born visible minority groups is between 32 and 35 . The immigrant non-minority groups average about 45 years old. Age at arrival has an average of 22 and 26, for non-minority and visible minority immigrants, respectively. The proportion of those who use different languages at home and work is quite variable, ranging from $16 \%$ for the Canadian born non-minority males to $85 \%$ for immigrant visible minority females. 
Maria Adamuti-Trache and Robert Sweet

Table 1

Profiles of respondents by immigrant status, visible minority and gender

\begin{tabular}{|c|c|c|c|c|c|c|c|c|}
\hline \multirow{3}{*}{$\begin{array}{c}\text { Immigrant status } \\
\text { Visible Minority } \\
\text { Gender }\end{array}$} & \multicolumn{4}{|c|}{ Canadian Born } & \multicolumn{4}{|c|}{ Immigrant } \\
\hline & \multicolumn{2}{|c|}{ No } & \multicolumn{2}{|c|}{ Yes } & \multicolumn{2}{|c|}{ No } & \multicolumn{2}{|c|}{ Yes } \\
\hline & Male & Female & Male & Female & Male & Female & Male & Female \\
\hline \multicolumn{9}{|l|}{ INDIVIDUAL } \\
\hline \multicolumn{9}{|l|}{ Age } \\
\hline Mean & 41 & 40 & 35 & 32 & 47 & 44 & 42 & 40 \\
\hline (SD) & (10) & (9) & (9) & (7) & (10) & (9) & (10) & (9) \\
\hline \multicolumn{9}{|l|}{ Age at arrival } \\
\hline Mean & NA & NA & NA & NA & 23 & 22 & 27 & 24 \\
\hline (SD) & & & & & (14) & (13) & (12) & (10) \\
\hline \multicolumn{9}{|l|}{ Language disadvantage } \\
\hline $\mathbf{N}$ & 300 & 470 & 30 & 40 & 220 & 180 & 440 & 290 \\
\hline$(\%)$ & (16) & (26) & (53) & (54) & (63) & $(65)$ & (84) & (85) \\
\hline \multicolumn{9}{|l|}{ EDUCATION } \\
\hline \multicolumn{9}{|l|}{ Canadian Education } \\
\hline $\mathbf{N}$ & 1770 & 1820 & 50 & 60 & 160 & 130 & 190 & 140 \\
\hline$(\%)$ & (96) & (98) & (90) & (92) & (46) & (45) & (37) & (41) \\
\hline \multicolumn{9}{|l|}{ Highest level } \\
\hline \multicolumn{9}{|l|}{ Undergraduate } \\
\hline $\mathbf{N}$ & 1520 & 1590 & 50 & 60 & 260 & 200 & 400 & 270 \\
\hline$(\%)$ & $(83)$ & $(86)$ & (86) & (88) & (72) & (71) & (76) & (80) \\
\hline \multicolumn{9}{|l|}{ Graduate } \\
\hline $\mathbf{N}$ & 320 & 260 & 10 & 10 & 100 & 80 & 130 & 70 \\
\hline$(\%)$ & (17) & (14) & (16) & (14) & (28) & (29) & (24) & (20) \\
\hline \multicolumn{9}{|l|}{ Program type } \\
\hline \multicolumn{9}{|l|}{ Liberal arts } \\
\hline $\mathbf{N}$ & 520 & 550 & 20 & 30 & 100 & 100 & 100 & 100 \\
\hline$(\%)$ & (28) & (30) & (33) & (45) & (27) & (36) & (19) & (30) \\
\hline \multicolumn{9}{|l|}{ Applied } \\
\hline $\mathbf{N}$ & 1320 & 1310 & 40 & 40 & 260 & 180 & 420 & 240 \\
\hline$(\%)$ & (72) & (71) & (67) & (55) & (73) & (64) & (81) & (70) \\
\hline \multicolumn{9}{|l|}{ EARNINGS } \\
\hline Mean & 74630 & 49340 & 69660 & 43420 & 76070 & 48090 & 54130 & 39620 \\
\hline (SD) & $(61170)$ & $(32460)$ & $(60970)$ & $(23280)$ & $(54460)$ & $(43090)$ & $(42450)$ & (27970) \\
\hline $\begin{array}{c}\text { Research sample } \\
(\mathbf{N}=\mathbf{5 3 2 0})\end{array}$ & 1840 & 1860 & 60 & 70 & 350 & 280 & 520 & 340 \\
\hline
\end{tabular}


The educational variables selected for this analysis are: origin of highest university degree, level of highest degree and type of degree (liberal arts or applied). Canadian credentials are expected to be more readily accepted in the labour market, which, of course, benefits over $97 \%$ of the Canadian-born respondents. While $46 \%$ of the non-minority immigrant groups possess Canadian education, only $38 \%$ of visible minority immigrants have this advantage, which may result from the more recent arrival of the latter group. Overall, larger proportions of immigrants (26\%) as compared to the Canadianborn $(16 \%)$ posses graduate degrees. The distribution of respondents across field of study is more uniform with the largest proportion of graduates of applied programs among the male visible-minority immigrants (81\%) and the lowest proportion among the female non-minority immigrants (55\%).

The last characteristic in Table 1 shows the total income that respondents obtained through employment. Differences between Canadian-born and immigrants are negligible for the non-minority groups, but become quite large for visible-minority immigrants who also happen to have higher proportions of foreign educated graduates.

\section{Immigrant and Non-Immigrant Comparison of Earnings}

We performed OLS regression analysis to predict earnings (natural log) by the set of variables previously discussed primarily to assess the effect of credentials when controlling for immigrant and visible minority status, gender, Canadian work experience, and language disadvantage. Table 2 shows results for the analysis of predicted earnings developed in 3 steps.

The Model I summary shows that $9 \%$ of the variability in earnings is explained by individual factors, and all are statistically significant. Earnings disadvantages are associated with immigrant status, and especially with minority status and gender. Females earn significantly less than males. The language workplace advantage and Canadian work experience predictors introduced in Model II raise the explained variability in outcome to $16 \%$. Their effects on earnings show that more years of Canadian work experience leads to increased earnings. For those speaking different languages at home and work there is a significant earnings penalty. 
Maria Adamuti-Trache and Robert Sweet

Table 2

Regression Model $(\mathbf{N}=5320)$

Unstandardized Coefficients (Standard Errors)

\begin{tabular}{|c|c|c|c|}
\hline Variables in the equation & Model I & Model II & Model III \\
\hline (Constant) & $11.031 * *[.016]$ & $10.615 * *[.028]$ & $10.511 * *[.032]$ \\
\hline Immigrant status $(\mathrm{No}=0 ;$ Yes $=1)$ & $-.084 *[.029]$ & $-.021 \quad[.030]$ & $.039 \quad[.035]$ \\
\hline Visible minority $(\mathrm{No}=0 ;$ Yes $=1)$ & $-.222 * *[.034]$ & $-.084 *[.033]$ & $-.020 \quad[.038]$ \\
\hline Gender $($ Male $=0 ;$ Female $=1)$ & $-.424 * *[.020]$ & $-.409^{* *}[.020]$ & $-.400 * *[.020]$ \\
\hline Canadian work experience (years) & & $.056^{* *} \quad[.004]$ & $.053^{* *}[.004]$ \\
\hline Squared Canadian work experience & & $-.001 * * \quad[.000]$ & $-.001 * * \quad[.000]$ \\
\hline Language disadvantage $(\mathrm{No}=0 ; \mathrm{Yes}=1)$ & & $-.178 * * \quad[.024]$ & $-.159 * * \quad[.024]$ \\
\hline Origin of education (Canada=ref) & & & \\
\hline USA/UK & & & $-.014 \quad[.046]$ \\
\hline Europe & & & $-.174 *[.058]$ \\
\hline Others & & & $-.314 * *[.044]$ \\
\hline Highest level of education & & & \\
\hline$($ Undergrad $=0 ;$ Graduate $=1)$ & & & $.172 * *[.026]$ \\
\hline Program type $($ Liberal=0; Applied=1) & & & $.133 * *[.022]$ \\
\hline Model summaries & $\mathbf{R}^{2}-\cap \cap 80$ & $\mathbf{R}^{2}-\cap 16 \Omega$ & $\mathbf{D}^{2}-\cap 170$ \\
\hline \& ANOVA tests & $\mathrm{F}=174.5 * *$ & $\mathrm{~F}=169.3^{* *}$ & $\mathrm{~F}=106.4 * *$ \\
\hline
\end{tabular}

$* \mathrm{p}<0.05 * * \mathrm{p}<0.01$ 
The full model introduces the set of credentials predictors. The proportion of variability in earnings explained is slightly increased to $18 \%$. As expected, origin of education matters indicating that foreign education is valued less in the labour market, especially if the degree was obtained in Europe or Other countries (which are primarily non-English or French speaking). Graduate degrees are better rewarded in the labour market, which may give some advantage to those immigrant groups with larger numbers of graduate degrees. Degrees in applied fields of study have a better income return, which would advantage males generally but especially male immigrants. When controlled by individual and work-related variables, all three dimensions of educational credentials account for earnings.

While visible-minority status and to some extent immigrant status have less effect in further modeling steps, gender remains a strong predictor of earnings. And the effects of both Canadian work experience and language (dis)advantage remain stable. This is consistent with other studies of the Canadian labour market that indicate the presence of distinct gender biases. When controlled for these factors, the effect on earnings of educational credentials is modest. Nevertheless, there is sufficient variability in their relationship to earnings to indicate that the labour market experience of immigrants is influenced by features of their educational credentials.

\section{Immigrant Education and Earnings}

In this section we will examine in greater detail the earnings of immigrants in relation to the three dimensions of their educational credentials. The previous analysis has shown that earnings vary by social structural factors (gender and visible-minority status) and that work and language related factors are significant determinants of earnings. Therefore, we control for work experience and language competence in comparing earnings of the four immigrant groups differentiated by visible minority status and gender. Tables A1 to A3 in the Appendix contain the observed earnings for the four immigrant groups by origin of education, educational level and field of study, and ANOVA statistics of main effects (e.g., group and origin of education)..

\section{Origin of Education}

Because the distribution of immigrants across the four categories of origin of education (Canada, US \& UK, Europe, Other) did not have sufficient numbers in some cells (e.g. small numbers of visible-minority immigrants from Europe), for the purpose of this analysis, groups that obtained education in Europe and 
Other countries are aggregated. As Figure 1 shows, earnings for an education received in the United States or Great Britain is not significantly different than earnings for a Canadian education.

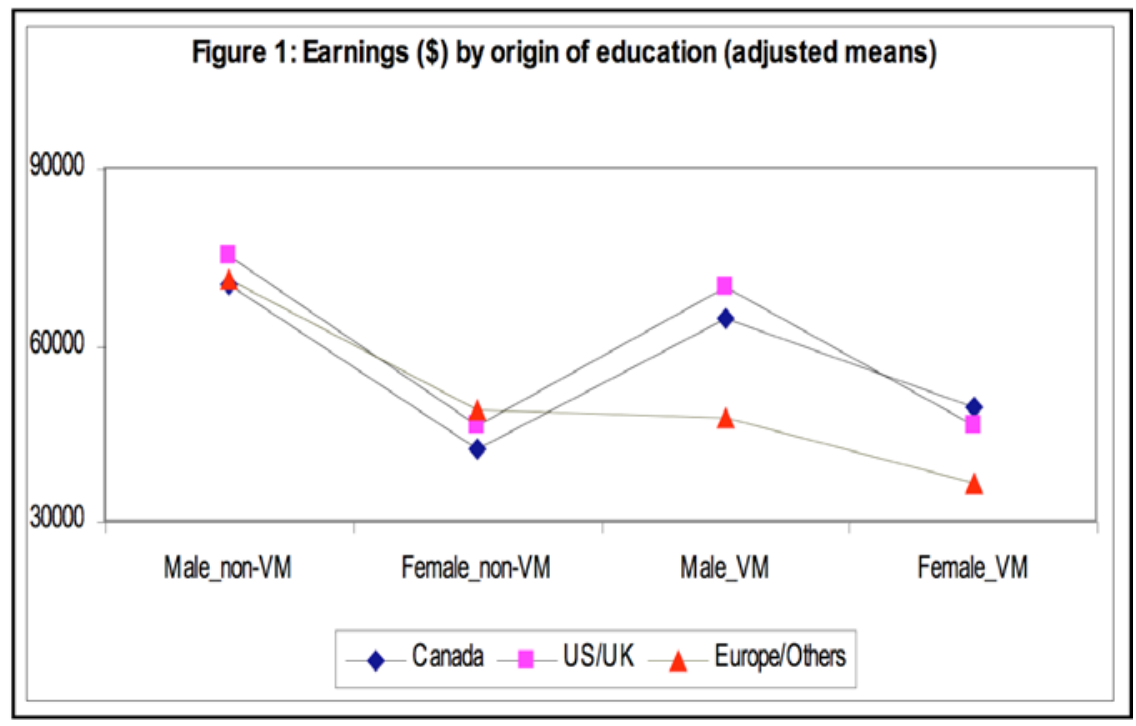

After adjusting for years of Canadian work experience and language advantage, the main effects of the gender-minority and origin of education factors remained significant (Table A1). This is mainly due to the male and female visible minority groups educated in non-English speaking countries who earn substantially less than those educated in Canada. While women educated in Canada have comparable earnings irrespective of minority status, differences in earnings up to $20 \%$ are noticed for men. The most advantaged immigrants in the labour market are men from non-minority groups, either educated in Canada, United States or Great Britain. The less advantaged are women from visible minority groups, especially when educated in non-Anglophone countries.

\section{Highest Level of Education}

Observed earnings by level of university education are shown in Figure 2. As expected, graduate education results in significantly higher income for all groups (about $20 \%$ more). This premium is somewhat lower for visible minority women, for whom earnings obtained by those possessing undergraduate degrees only the lowest of any group. For those with graduate degrees higher earnings 
are achieved by all four gender and visible-minority status groups.

After adjusting for Canadian work experience and language advantage the main effects of gender-minority and level of education factors remained significant (Table A2). While women with similar qualifications have similar earnings, irrespective of minority status, significant differences exist between the two male groups.

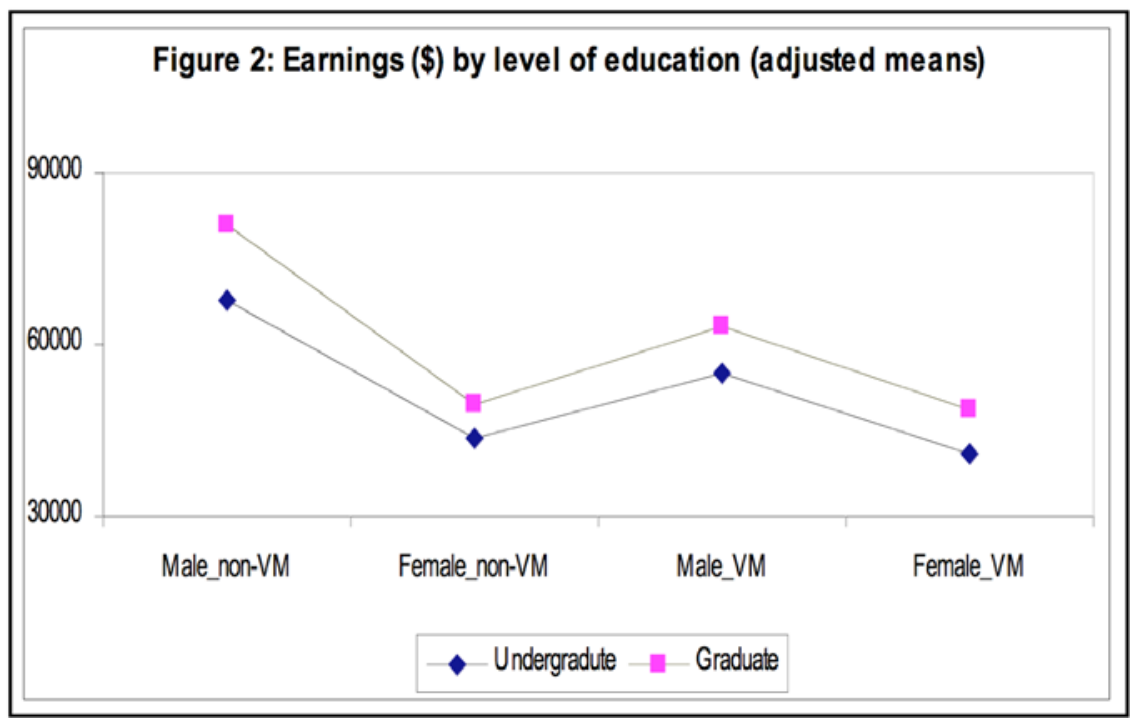

\section{Field of Study}

Consistent with previous studies (e.g. Lin, Sweet \& Anisef, 2003) the analysis of earnings shows that applied degrees are associated with higher or equal income levels for all groups. Figure 3 shows earnings differences between liberal arts and applied fields are greater (about $25 \%$ ) for the minority groups, both women and men. Within each field, differences by gender and visible minority status are pronounced. Belonging to a visible minority group leads to lower earnings, especially for female liberal arts graduates.

After controlling for years of Canadian work experience and language advantage, the main effects of gender-minority group and field of study factors remained significant. On average, women have similar earnings, irrespective of minority status, but significant differences are noticed between non-minority and minority male groups. Overall, it appears that an education premium can be 
achieved along three dimensions, with earnings advantage resulting from either a Canadian, American or British education, and from possessing graduate degrees in applied fields. Education received in non-Anglophone countries is largely discounted, especially at the undergraduate, liberal arts field.

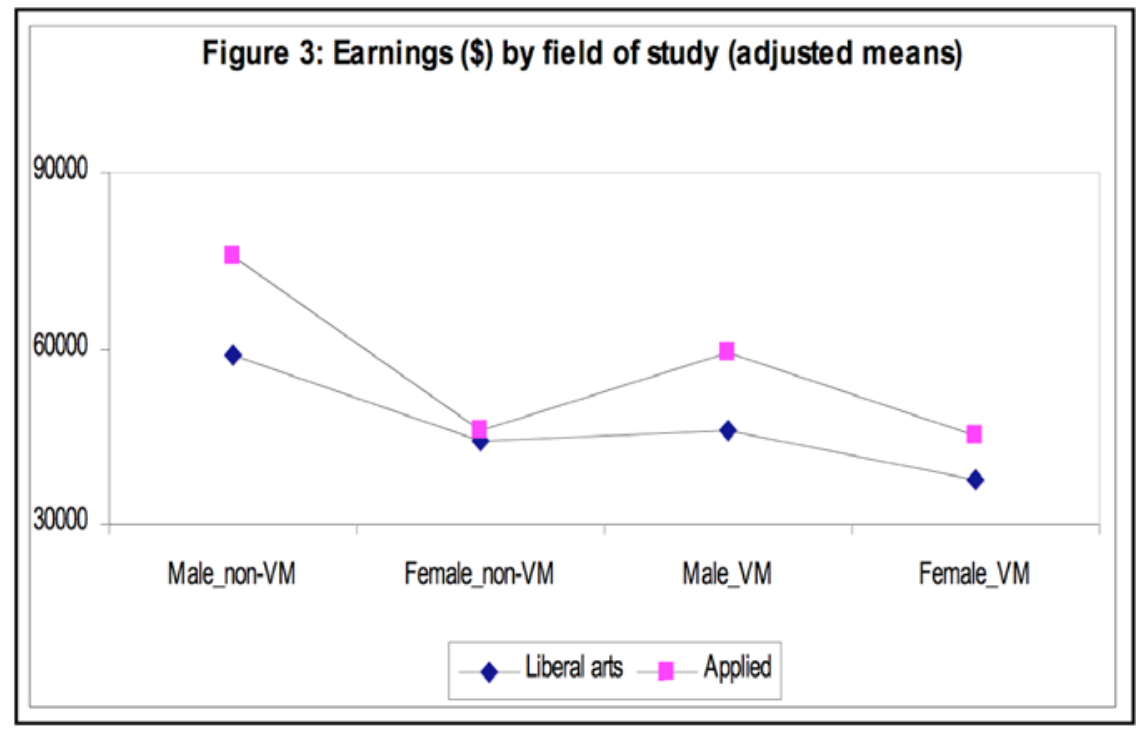

\section{Summary and Discussion}

The main finding of this paper is that social categories (gender, immigrant status and visible minority) account for the largest proportion of variation in earnings for university degrees holders. Other significant factors influencing earnings are more contextual, like years of Canadian work experience and language proficiency. When comparing Canadian born with immigrants, the negotiation of credentials in the labour market is significantly determined by origin of education, level of education and field of study. Earnings advantages are created for holders of graduate degrees in applied fields who obtained their education in Canada or an English-speaking country.

The typical earnings ratio of 65 cents earned by women for every dollar earned by men is observed for various groups of immigrants independent of their educational credentials. Since clear income disparities also can be observed for Canadian born women it implies that gender inequity in earnings is a persistent 
labour market issue; and one that is amplified for immigrant women. Foreign education is still penalized for visible minority immigrants and women. However, minority groups holding graduate and/or applied degrees approach earnings parity more readily than those with undergraduate liberal arts degrees. The 'immigrant adjustment' period for these individuals may be shorter. These findings nevertheless indicate that the Canadian labour market remains gendered and systemically biased. Gender, race, and ethnicity are still barriers to full economic integration. That immigrant status often intersects with these features obviously worsens individual integration opportunities. Further research is needed to separate the effects of the various sources of bias.

Worswick (2004) argues that since transferability of foreign education into the Canadian labour market is not operating and work experience in the home country is not valued by Canadian employers, a Canadian immigration policy that places major emphasis on human capital needs to be revised. Tolley (2003) analyzes the research on immigration selection criteria and notes that language proficiency appears to be the most reliable determinant of economic integration. Tolley supports a shift in the Immigration policy from the human capital system toward occupation-based criteria (e.g., Australian system) and suggests that comparative research of economic outcomes of immigrants selected under different systems would be illuminating. Our findings reinforce the importance of language competence. While education is a strong factor that differentiates economic outcomes within the immigrant group, foreign education and foreign work experience, especially from non-anglophone or francophone source countries does not bring comparable earnings.

It is not uncommon that immigrants are forced to abandon their previous credentials and to consider new avenues in the Canadian educational system and the labour market in order to secure stable, well-remunerated employment. Going back to school, working in jobs that do not match their educational training or work experience, doing multiple jobs, and changing careers are common ways in which immigrants better their position in the Canadian labour market. Even if these pathways to economic integration are not new in the history of immigration, the fact that highly educated newcomers -- who have been accepted to Canada because of their skills and education -- have to follow such inefficient routes to satisfactory employment leads to an overall economic loss for both individuals and the Canadian society.

The response may be a modification to the immigration selection criteria as suggested by Worswick, Tolley and others. However, it may be equally useful to examine the processes of social capital acquisition and its role in engaging human capital. While the present study reveals existing and persistent earnings inequalities among highly educated immigrants, the findings also show that 
Maria Adamuti-Trache and Robert Sweet

some groups of immigrants are quite successful in negotiating their educational credentials in the labour market, at times exceeding earnings levels of the Canadian born. Future research might usefully explore the means by which these groups engage in the social processes of job-finding and career development.

\section{End Notes:}

1. Additional analysis at the level of major fields of study would be desirable. However, low counts for some of the design groups introduces large errors.

2. ${ }^{1}$ Counts are rounded to the nearest tens and proportions to the nearest unit. Means (and standard deviations) are rounded to the nearest unit, while measures of earnings are rounded to the nearest tens.

\section{References:}

Allen, M., Harris, S., Butlin, G. (2003). Finding their way: a profile of young Canadian graduates. Catalogue no. 81-595-MIE, Ministry of Industry $\&$ Statistics Canada

Allen, R. (1998). The employability of university graduates in the humanities, social sciences, and education: Recent statistical evidence. Discussion Paper No.98-15, Department of Economics, The University of British Columbia, Vancouver, B.C.

Anisef, P., Sweet, R. \& Frempong, G. (2002). Labour Market Outcomes of Immigrant and Racial Minority University Graduates in Canada. Centre of Excellence for Research on Immigration and Settlement (CERIS) Working Paper Series: Toronto

Aydemir, A. \& Skuterud, M. (2004). Explaining the Deterioration Entry Earnings of Canada's Immigrant Cohorts: 1966-2000. Catalogue no. 11F0019MIE. Statistics Canada, Family and Labour Studies Division.

Baldwin, J. R., \& Beakstead, D. (2003). Knowledge workers in Canada's economy, 1971-2001. Catalogue no. 11-624-MIE - No. 004, Statistics Canada, Micro-economic Analysis Division.

Beach, C. and Worswick, C. (1993). "Is there a double negative effect on the earnings of immigrant women?," Canadian Public Policy, 19: 36-53. 
Exploring the Relationship between Educational Credentials and the Earnings of Immigrants

Beakstead, D. \& Vinodrai, T. (2003). Dimensions of Occupational Changes in Canada's Knowledge Based Economy, 1971-1996. Catalogue no. 11622-MIE - No. 004. Statistics Canada, Micro-economic Analysis Division.

Boothby, D. (2000). Earnings Differences by Detailed Field of Study of University Graduates, Research Paper R-00-1-5E. Ottawa. Human Resources Development Canada and Statistics Canada.

Boyd, M. (1992) Gender, visible minority and immigrant earnings inequality: reassessing an employment equity premise. In V. Satzewich (ed.), Deconstructing a Nation: Immigration, Multiculturalism and Racism in 1990s Canada. Halifax: Fernwood Publishing and Saskatoon, University of Saskatchewan, Department of Sociology, Social Science Research Unit, pp. 279-321.

Davies, S. and Guppy. N. (1998). Race and Canadian Education. in Vic Satzewich (ed). Racism and Social Inequality in Canada: Concepts, Controversies and Strategies of Resistance.Toronto: Thompson Educational Publishing Inc.

Ferrer, A. \& Riddell, C. (2004). Education, Credentials and Immigrant Earnings. TARGET Working Paper 020.

Finnie, R. (2001). Fields of Plenty, Fields of Lean: The Early Labour Market Outcomes of Canadian University Graduates by Discipline. The Canadian Journal of Higher Education, Vol. XXXI, No. 1, pp.141176.

Frenette, M. \& Morissette, R. (2003). Will they ever converge? Earnings of immigrant and Canadian-born workers over the last two decades. Analytical Studies Research Paper No. 215, Statistics Canada.

Heisz, A. (2003). Relative earnings of British Columbia university graduates. Education Quarterly Review, vol. 9, no.1, pp. 35-47. Ottawa: Statistics Canada

Hiebert, D. (1997). The Colour of Work: Labour Market Segmentation in Montreal, Toronto, and Vancouver, 1991, Working Paper No. 97-02. Vancouver: RIIM. 
Maria Adamuti-Trache and Robert Sweet

Kunz, J., Milan, A., and Schetagne, S. (2000). Unequal Access: A Canadian Profile of Racial Differences in Education, Employment and Income. A Report Prepared for the Canadian Race Relations Foundation. Toronto: Canadian Race Relations Foundation.

Kunz, J. (2003). Being young and visible: labour market access among immigrant and visible minority youth - final report. Applied Research Branch Paper SP-581-08-03E. Gatineau, Québec: Human Resources Development Canada,

Lavoie, M. and R. Roy. (1998). Employment in the Knowledge-Based Economy: A Growth Accounting Exercise for Canada. Applied Research Branch Research Paper R-98-8E. Ottawa: Human Resources Development Canada.

Li, P.S. (2001). The Market Worth of Immigrants' Educational Credentials, Canadian Public Policy, 27, No.1.

Li, P.S. (2003). Destination Canada: Immigration Debates and Issues. Toronto: Wall and Thompson.

Lin, Z., Sweet, R., Anisef, P. (2003). Consequences and Policy Implications for University Students Who Have Chosen Liberal or Vocational Education in Canada: Labour Market Outcomes and Employability Skills. Higher Education Policy, 16, pp.55-85.

Morissette, R., Ostrovsky, Y. \& Picot, G. (2004). Relative Wage Patterns among the Highly Educated in a Knowledge-based Economy. Catalogue no. 11F0019MIE - No. 232, Statistics Canada. Business and Labour Market Analysis Division

Picot, G. \& Hou, F. (2003). The rise in low-income rates among immigrants in Canada. Catalogue no. 11F0019MIE. Statistics Canada, Business and Labour Market Analysis Division

Picot, G. (2004). The Deteriorating Economic Welfare of Immigrants and Possible Causes. Catalogue no. 11F0019MIE, Statistics Canada, Business and Labour Market Analysis Division

Reitz, J. (2000). Immigrant success in the knowledge economy: Institutional change and the immigrant experience in Canada, 1970-1995. Unpublished paper. The University of Toronto, Toronto, ON. 
Exploring the Relationship between Educational Credentials and the Earnings of Immigrants

Reitz, J. G. (2001). Immigrant Skill Utilization in the Canadian Labour Market: Implications of Human Capital Research. Journal of International Migration and Integration, 2(3), (pp. 347-378)

Reitz, J. G. (2005). Tapping Immigrants' Skills. New Directions for Canadian Policy in the Knowledge Economy. IRPP (Immigration and Refugee Policy) Choices, 11(1) (pp. 2-18).

Statistics Canada (2003a). The Canadian Labour Market at a Glance. Catalogue no. 71-222-XIE, Statistics Canada, Labour Statistics Division.

Statistics Canada (2003b). Earnings of Canadians: Making a Living in the New Economy. 2001 Census analysis series, Catalogue no. 96F0030XIE, Statistics Canada.

Statistics Canada (2003c). Education in Canada: Raising the Standard. 2001 Census analysis series, Catalogue no. 96F0030XIE, Statistics Canada.

Statistics Canada (2003d). Education Indicators in Canada: Report of the PanCanadian Education Indicators Program 2003. Catalogue no. 81-582-XIE, Statistics Canada

Sweetman, A., McBride, S. (2004). Postsecondary Field of Study and the Canadian Labour Market Outcomes of Immigrants and NonImmigrants. Ottawa: Human Resources and Skills Development Canada.

The Conference Board of Canada (2004). Performance and Potential 20042005: Key Findings. How Can Canada Prosper in Tomorrow's World? Retrieved August 31, 2005 from www.conferenceboard.ca

Thompson, E. N. (2000). Immigrant Occupational Skill Outcomes and the Role of Region-of-Origin-Specific Human Capital. Applied Research Branch Research Paper W-00-8E. Ottawa: Human Resources Development Canada.

Tolley, E. (2003). The Skilled Worker Class. Selection Criteria in the Immigration and Refugee Protection Act. Metropolis Policy Brief no. 1 (pp. 1-8). 
Maria Adamuti-Trache and Robert Sweet

Worswick, C. (2004). Immigrants' Declining Earnings: Reasons and Remedies. C. D. Howe Institute Backgrounder. Retrieved August 31, 2005 from: www.cdhowe.org

\section{Appendix}

Table A1: Earnings by Origin of education

\begin{tabular}{lcccc}
\hline \multicolumn{1}{c}{ Visible Minority } & \multicolumn{2}{c}{ No } & \multicolumn{2}{c}{ Yes } \\
\hline Canadian educated & Male & Female & Male & Female \\
Mean & & & & \\
(SD) & 78960 & 48060 & 65600 & 47280 \\
N & $(58080)$ & $(36860)$ & $(39890)$ & $(33320)$ \\
& 160 & 130 & 190 & 130 \\
\hline United States and UK & & & & \\
Mean & 82000 & 53510 & 66860 & 44240 \\
(SD) & $(35730)$ & $(26050)$ & $(68100)$ & $(19150)$ \\
N & 60 & 50 & 60 & 20 \\
& & & & \\
\hline Europe \& Other & & & & \\
Mean & & & & \\
(SD) & 69340 & 44750 & 43530 & 32280 \\
N & $(56020)$ & $(54220)$ & $(35600)$ & $(22790)$ \\
& 130 & 110 & 270 & 180 \\
\hline
\end{tabular}

Main effects:

Group: $F(3,1482)=23.02, p<0.001$

Origin of education: $\mathrm{F}(2,1482)=3.25, \quad \mathrm{p}<0.05$ 
Exploring the Relationship between Educational Credentials and the Earnings of Immigrants

Table A2: Earnings by Highest level of education

\begin{tabular}{|c|c|c|c|c|}
\hline \multirow[t]{2}{*}{ Visible Minority } & \multicolumn{2}{|c|}{ No } & \multicolumn{2}{|c|}{ Yes } \\
\hline & Male & Female & Male & Female \\
\hline $\begin{array}{l}\text { Undergraduate } \\
\text { Mean } \\
\text { (SD) } \\
\text { N }\end{array}$ & $\begin{array}{c}72220 \\
(55630) \\
260\end{array}$ & $\begin{array}{c}45220 \\
(46350) \\
200\end{array}$ & $\begin{array}{c}51740 \\
(36790) \\
400\end{array}$ & $\begin{array}{c}38290 \\
(27760) \\
270\end{array}$ \\
\hline $\begin{array}{l}\text { Graduate } \\
\text { Mean } \\
\text { (SD) } \\
\text { N }\end{array}$ & $\begin{array}{c}85940 \\
(50270) \\
100\end{array}$ & $\begin{array}{c}55040 \\
(33170) \\
80\end{array}$ & $\begin{array}{c}61670 \\
(56250) \\
130\end{array}$ & $\begin{array}{c}44960 \\
(28410) \\
70\end{array}$ \\
\hline
\end{tabular}

Table A3: Earnings by Field of study

\begin{tabular}{lcccc}
\hline \multicolumn{1}{c}{ Visible Minority } & \multicolumn{2}{c}{ No } & \multicolumn{2}{c}{ Yes } \\
\hline \multicolumn{1}{c}{ Liberal arts } & Male & Female & Male & Female \\
Mean & & & & \\
(SD) & 72350 & 47510 & 45030 & 33280 \\
N & $(47640)$ & $(54650)$ & $(23990)$ & $(19850)$ \\
& 100 & 100 & 100 & 100 \\
\hline Applied & & & & \\
Mean & & & & \\
(SD) & 77470 & 48420 & 56310 & 42300 \\
N & $(56830)$ & $(34950)$ & $(45530)$ & $(30410)$ \\
& 260 & 180 & 420 & 240 \\
\hline
\end{tabular}

Main effects: $\quad$ Group: $F(3,1486)=3.60, p<0.001$

Field of study: F $(1,1486)=15.73, \mathrm{p}<0.001$ 